\title{
Combined Water Extraction and Sodium Chlorite Pretreated Spent Mushroom Compost for Protease Production by Separate Hydrolysis and Fermentation and Simultaneous Saccharification and Co-fermentation
}

\author{
Pei Lu, ${ }^{\text {a } B i n-B i n ~ H u, ~}{ }^{\text {b }}$ Yu-Tao Wang, ${ }^{\mathrm{c}, \mathrm{d}}$ and Ming-Jun Zhu ${ }^{\mathrm{a}, \mathrm{c}, \mathrm{d}, *}$
}

\begin{abstract}
A process of simultaneous saccharification and protease production was successfully established from spent mushroom compost (SMC) created through edible fungi cultivation. The combined water extraction and sodium chlorite pretreatment significantly $(p<0.05)$ improved enzymatic digestibility of SMC, which led to a reducing sugar yield of $0.759 \mathrm{~g} / \mathrm{g}$ that was 12 times higher than raw SMC. The water extract from SMC was recycled for simultaneous saccharification and protease production from pretreated SMC by Bacillus subtilis DES-59, which promoted the protein concentration and neutral protease activity by $21.9 \%$ and $11.6 \%$, respectively. The simultaneous saccharification and co-fermentation (SScF) of pretreated SMC by Bacillus subtilis DES-59 produced 5518 $\mathrm{U} / \mathrm{mL}$ protease, which was superior to the separate hydrolysis and fermentation (SHF) process. Fermentation residues containing Bacillus subtilis cells could be further converted into fertilizer. The closed-loop utilization of SMC was achieved using established processes, which indicates potential for application in future biorefineries.
\end{abstract}

Keywords: Extract; Protease production; Spent mushroom compost; Sodium chlorite; Fertilizer

Contact information: a: Guangdong Provincial Engineering and Technology Research Center of Biopharmaceuticals, School of Biology and Biological Engineering, South China University of Technology, Guangzhou Higher Education Mega Center, Panyu, Guangzhou 510006, People's Republic of China; b: Yunnan Academy of Tobacco Agricultural Sciences, Kunming 650021, People's Republic of China; c: College of Life and Geographic Sciences, Kashi University, Kashi 844000, People's Republic of China; $d$ : The Key Laboratory of Ecology and Biological Resources in Yarkand Oasis at Colleges and Universities under the Department of Education of Xinjiang Uygur Autonomous Region, Kashi University, Kashi 844000, People's Republic of China; *Corresponding author: mjzhu@scut.edu.cn

\section{INTRODUCTION}

Protease, one of the three major industrial enzymes, accounts for approximately $60 \%$ of global enzyme sales (Hussain et al. 2017). It has been widely applied in food, detergent, antineoplastic drugs, and feed additives (Hmidet et al. 2009). Protease has been produced from inexpensive and readily available agricultural residues, such as wheat bran, rice bran, and sugarcane bagasse. As the world's largest solid-state fermentation industry, the annual edible mushroom yield is huge. Many industrial and agricultural wastes, such as sawdust, cottonseed husk, and corn cob, have been used as media for edible fungi cultivation. $5 \mathrm{~kg}$ SMC will be generated from $1 \mathrm{~kg}$ mushroom production. In 2013, the output of spent mushroom compost reached hundreds of millions of tons (Carrasco et al. 2018). Waste SMC has caused environmental concerns. However, compared to other residues, some nutrients remain in SMC. Meanwhile, SMC, as a kind of lignocellulose, is mainly composed of cellulose and hemicellulose, which can be 
hydrolyzed into monosaccharide mixtures (glucose, xylose, and arabinose). Bacillus subtilis DES-59 (Zhu et al. 2013b), a protease producing strain, which can utilize both xylose and glucose, may be used to produce protease from SMC and improve the conversion efficiency of SMC compared with a single sugar utilization strain (Asada et al. 2011). Therefore, there is potential to produce protease from SMC by Bacillus subtilis DES-59.

The recalcitrant structure of SMC suggests that pretreatment is required prior to enzymatic hydrolysis. Organosolv, alkaline peroxide, dilute-acid, and steam-exploded pretreatment have been conducted on SMC (Asada et al. 2011; Kapu et al. 2012; Zhu et al. 2016; Lin et al. 2017). Dilute-acid pretreatment and steam-exploded pretreatment were both carried out at a high temperature. Organosolv pretreatment is expensive, and alkaline peroxide is difficult to recycle. Considering the efficacy and economy, it is preferable to develop an efficient pretreatment process. Acid-chlorite pretreatment has proven to be a valid process for removing lignin (Hubbell and Ragauskas 2010). During the pretreatment, the $\mathrm{ClO}_{2}$ is released in an acidic environment and oxidizes lignin as a highly active bleach. Cellulose has been obtained from water hyacinth and softwood with high conversion rates by acid-chlorite pretreatment (Yu et al. 2011; Abdel-Fattah and Abdel-Naby 2012). Sodium chlorite pretreatment has also been employed to improve the digestibility of lignocellulose (Nan et al. 2018).

The water extract of lignocellulose is a non-negligible part composed of proteins, sugar, phenolics, and so on (Chen et al. 2007). The presence of water extract components is reported to impact not only the composition analysis, but also the effectiveness of pretreatment. Furthermore, the reactions between lignin and extract during the pretreatment impact the enzymatic hydrolysis efficiency of the pretreated samples (Martín et al. 2015). Therefore, the water extraction process before pretreatment is necessary. Because the water extract of SMC is composed of nitrogen, sugar, and metal ions, the water extract may be recycled for proteases production to avoid the loss of water-soluble nutrients. In this way, the production cost of protease can be reduced. However, the utilization of water extract for protease production has not been reported.

In addition, the fermentation process will affect the production of the desired product as well. Solid state fermentation is a traditional strategy for enzyme production utilizing agriculture by-products. However, in this study, the submerged fermentation was introduced due to its convenient product separation, sufficient oxygen transfer, lower fermentation time, and easy monitoring of fermentation parameters (Gomes et al. 1994; Cerda et al. 2019). Separate hydrolysis and fermentation (SHF) and simultaneous saccharification and co-fermentation $(\mathrm{SScF})$ are traditional processes for lignocellulose utilization. SHF decouples enzymatic hydrolysis and fermentation steps as separate processes to be performed under two optimum conditions. The two separate steps require more reactors and present lower efficiency (Cannella and Jørgensen 2014). SScF is considered to be an ideal strategy due to the integration of enzymatic hydrolysis and fermentation, which could solve the aforementioned problems. In addition, the SScF could convert glucose and xylose together into desired products during fermentation (Xu et al. 2018). The lignocellulosic fermentation residues have been recommended for conversion into fertilizer (Zhu et al. 2013a; Quintanar-Orozco et al. 2018; Smitha et al. 2019). Such a product not only improves the soil fertility for sustainable agriculture, but also provides a viable means of waste disposal.

The present study focused on the potential of SMC for protease production. Combined water extraction and sodium chlorite pretreatment was conducted to improve 
the digestibility of SMC. The water extractives of SMC and pretreated SMC were used for protease production by SHF and SScF. The residues after SScF could be reused as fertilizer back to agricultural production, thereby achieving a closed-loop utilization of SMC.

\section{EXPERIMENTAL}

\section{Materials}

Flammulina velutipes SMC used in this study was kindly provided by Starway Biotechnology Co., Ltd. (Guangdong province, China). The medium for the cultivation of Flammulina velutipes mainly consisted of cottonseed hull, wheat bran, corn powder, corncob, and wood chips. SMC was ground and screened through 100-mesh sieves for further use. Cellulase (CTec 2, $120 \mathrm{FPU} / \mathrm{mL}$ ) was purchased from Sigma Aldrich (St. Louis, MO, USA). The standard sugars for composition analysis were obtained from Aladdin (Shanghai Aladdin Bio-Chem Technology Co., Ltd., Shanghai, China). Sodium chlorite $(80 \%)$, trichloroacetic acid, casein, and tyrosine were purchased from Macklin (Shanghai Macklin Biochemical Co., Ltd., Shanghai, China).

\section{Methods}

Water extraction of the raw SMC

A sample of $40 \mathrm{~g} \mathrm{SMC} \mathrm{(dry} \mathrm{weight)} \mathrm{was} \mathrm{extracted} \mathrm{with} 400 \mathrm{~mL}$ water at $55^{\circ} \mathrm{C}$ for $2 \mathrm{~h}$ in a water bath with magnetic stirring. The water extracts were obtained by filtration and stored at $-20{ }^{\circ} \mathrm{C}$ for further study. Subsequently, the filter cake was dried overnight at $55{ }^{\circ} \mathrm{C}$ to remove water. Water extract was collected for composition analysis and protease production, and the dried cake was used for subsequent pretreatment.

\section{Orthogonal experiments design for pretreatment of SMC}

The extractive-free SMC was pretreated with sodium chlorite. The effect of conditions on the pretreatment was investigated by $\mathrm{L}_{16}\left(4^{4}\right)$ orthogonal design (Table 1$)$. The main factors of pretreatment included solid-to-liquid ratio (factor A), treatment time (factor B), temperature (factor C), and sodium chlorite concentration (factor D). Four levels of each factor were selected for the experiment. The pretreated solid was separated from the liquid by leaching at the end of pretreatment. The separated solid was washed to neutral with water and dried overnight at $55{ }^{\circ} \mathrm{C}$. A portion of the solid was used for composition analysis, and the rest was stored in sealed plastic bags for subsequent enzymatic hydrolysis. The lignin removal was calculated according to Eq. 1,

$$
\text { Lignin removal }(\%)=(29.9 \%-x) / 29.9 \% \times 100 \%
$$

where $x$ is lignin content in pretreated SMC (\%).

\section{Enzymatic hydrolysis}

A sample of $0.1 \mathrm{~g}$ pretreated SMC was soaked in $5 \mathrm{~mL} 50 \mathrm{mM}$ sodium citrate buffer ( $\mathrm{pH} 4.8$ ). The enzymatic hydrolysis was performed at $55{ }^{\circ} \mathrm{C}$ and $150 \mathrm{rpm}$ for $72 \mathrm{~h}$ with an enzyme loading of $20 \mathrm{FPU} / \mathrm{g}$ unless otherwise specified. The released reducing sugar concentration was determined using 3,5-dinitrosalicylic acid (DNS) for the enzymolysis efficiency calculation (Hong et al. 2019). 
To investigate the impact of water extract of SMC on reducing sugar yield, 30\%, $60 \%, 90 \%(\mathrm{v} / \mathrm{v})$ sodium citrate buffer was substituted by an equal volume of water extract. The initial $\mathrm{pH}$ of enzymatic hydrolysis was 4.8. The solid loading and working volume were $2 \%(\mathrm{w} / \mathrm{v})$ and $5 \mathrm{~mL}$, respectively. To investigate the effect of water extract on the growth of Bacillus subtilis DES-59, the enzymatic hydrolysis of 1g pretreated SMC was conducted in $50 \mathrm{~mL}$ water extract and deionized water, respectively. The hydrolysates were used for media preparation.

The enzymatic hydrolysis of $5 \mathrm{~g}, 10 \mathrm{~g}$, and $15 \mathrm{~g}$ pretreated samples was conducted at the same condition in $50 \mathrm{~mL}$ sodium citrate buffer. The enzymatic hydrolysis was performed for $96 \mathrm{~h}$. The obtained hydrolysates were stored at $-20{ }^{\circ} \mathrm{C}$ for further experiments.

Table 1. $\mathrm{L}_{16}\left(4^{4}\right)$ Orthogonal Experiments Designed for the Study

\begin{tabular}{|c|c|c|c|c|}
\hline Entry & $\mathrm{A}$ & $\mathrm{B}(\mathrm{h})$ & $\mathrm{C}\left({ }^{\circ} \mathrm{C}\right)$ & $\mathrm{D}(\%)$ \\
\hline 1 & $2: 20$ & 1 & 80 & 9 \\
\hline 2 & $2: 25$ & 1 & 70 & 10 \\
\hline 3 & $2: 15$ & 1 & 65 & 7 \\
\hline 4 & $2: 30$ & 1 & 75 & 8 \\
\hline 5 & $2: 30$ & 2 & 70 & 9 \\
\hline 6 & $2: 15$ & 2 & 80 & 10 \\
\hline 7 & $2: 20$ & 2 & 65 & 8 \\
\hline 8 & $2: 25$ & 2 & 75 & 7 \\
\hline 9 & $2: 15$ & 3 & 70 & 7 \\
\hline 10 & $2: 30$ & 3 & 80 & 10 \\
\hline 11 & $2: 20$ & 3 & 75 & 9 \\
\hline 12 & $2: 25$ & 3 & 65 & 8 \\
\hline 13 & $2: 15$ & 4 & 75 & 7 \\
\hline 14 & $2: 25$ & 4 & 80 & 10 \\
\hline 15 & $2: 20$ & 4 & 70 & 65 \\
\hline 16 & $2: 30$ & 4 & $1 \%$ & 9 \\
\hline
\end{tabular}

A: ratio of solid to liquid; B: time (h); C: temperature $\left({ }^{\circ} \mathrm{C}\right)$; D: sodium chlorite concentration $(\%)$

Separate hydrolysis and fermentation of pretreated SMC

Bacillus subtilis DES-59 was cultured for protease production. Pure culture of Bacillus subtilis DES-59 from LB agar-slant was inoculated into LB medium at $30{ }^{\circ} \mathrm{C}$ for $12 \mathrm{~h}$. The hydrolysates obtained at high solid loadings were diluted to $10 \mathrm{mg} / \mathrm{mL}, 20$ $\mathrm{mg} / \mathrm{mL}$, and $30 \mathrm{mg} / \mathrm{mL}$ (total reducing sugar) as carbon sources for protease production. Proportions of $10.5 \mathrm{~g} / \mathrm{L} \quad \mathrm{K}_{2} \mathrm{HPO}_{4}, 4.5 \mathrm{~g} / \mathrm{L} \quad \mathrm{KH}_{2} \mathrm{PO}_{4}, 1 \mathrm{~g} / \mathrm{L} \quad\left(\mathrm{NH}_{4}\right)_{2} \mathrm{SO}_{4}, 0.5 \mathrm{~g} / \mathrm{L}$ $\mathrm{Na}_{3} \mathrm{C}_{6} \mathrm{H}_{5} \mathrm{O}_{7} \cdot 2 \mathrm{H}_{2} \mathrm{O}$, and $0.2 \mathrm{~g} / \mathrm{L} \mathrm{MgSO}_{4} \cdot 7 \mathrm{H}_{2} \mathrm{O}$ were dissolved in $47.5 \mathrm{~mL}$ of the hydrolysates as fermentation medium. The media were autoclaved at $115{ }^{\circ} \mathrm{C}$ for $30 \mathrm{~min}$. Inoculation ratio was $5 \%(\mathrm{v} / \mathrm{v})$. The $250 \mathrm{~mL}$ flask was cultivated at $180 \mathrm{rpm}$ and $30{ }^{\circ} \mathrm{C}$. During the fermentation, the enzyme activity, $\mathrm{OD}_{600}$, glucose concentration, and xylose concentration were monitored. The number of bacteria was estimated by counting colony-forming units on agar plates. 


\section{Simultaneous saccharification and co-fermentation of pretreated SMC}

The $47.5 \mathrm{~mL}$ hydrolysates in the above-mentioned media were replaced by equal volume of deionized water and water extracts for SScF with $20 \mathrm{mg} / \mathrm{mL}, 40 \mathrm{mg} / \mathrm{mL}$, or 60 $\mathrm{mg} / \mathrm{mL}$ of pretreated SMC, $2.5 \mathrm{~mL}$ inoculum, and $20 \mathrm{FPU} / \mathrm{g}$ cellulase. The $250 \mathrm{~mL}$ flask was cultivated at $180 \mathrm{rpm}$ and $30{ }^{\circ} \mathrm{C}$. The fermentation broth was sampled every $12 \mathrm{~h}$ to determine fermentation parameters. At the end of fermentation, the residues were collected for composition analysis.

\section{Analytical methods}

The composition of SMC was determined according to the procedure of the National Renewable Energy Laboratory (Sluiter et al. 2012). The content of monomeric sugars was quantified using a Waters 2414 HPLC (Waters Corporation, Milford, MA, USA) at a flow of $0.6 \mathrm{~mL} / \mathrm{min}$ and $60{ }^{\circ} \mathrm{C}$ with $5 \mathrm{mM} \mathrm{H}_{2} \mathrm{SO}_{4}$ as the mobile phase, which was equipped with a refractive index detector and an Aminex HPX-87H column (BioRad, Hercules, CA, USA) (An et al. 2018). The surface morphological differences between SMC and pretreated SMC materials were observed by scanning electron microscope (SEM) (Merlin Compact, Carl Zeiss, Oberkochen, Germany). The magnification of the photographed images was 2000. The X-ray diffraction analysis (XRD) (Empyrean, PANalytical BV, Almelo, Holland) was performed according to a prior study (Zhang and Zhu 2016). The previous formula was applied to determine the crystallinity index (Lin et al. 2017). Fourier transformed infrared spectroscopy (FTIR) was conducted using a spectrometer (CCR-1; Thermo Nicolet, Shanghai, China) within the wavelength range of $400 \mathrm{~cm}^{-1}$ to $4000 \mathrm{~cm}^{-1}$, as previously described (Hong et al. 2019). The protein content in water extract was determined as 6.25 multiplied by total nitrogen, which was measured by the Kjeldahl method (Elsamadony and Tawfik 2018). The enzyme activity was assayed by a traditional method (Borhani et al. 2018). One mL of diluted broth was mixed with $1 \mathrm{~mL} 10 \mathrm{~g} / \mathrm{L}$ casein solution at $40{ }^{\circ} \mathrm{C}$ for $10 \mathrm{~min}$. The reaction was stopped by $2 \mathrm{~mL} 0.4 \mathrm{~mol} / \mathrm{L}$ trichloroacetic acid. The mixture was filtered after $10 \mathrm{~min}$. Then, $1 \mathrm{~mL}$ filtrate was mixed with $5 \mathrm{~m} \mathrm{~L}$ of $0.4 \mathrm{~mol} / \mathrm{L}$ sodium carbonate solution and $1 \mathrm{~mL}$ of Folin \& Ciocalteu's phenol reagent. The solution was maintained at $40{ }^{\circ} \mathrm{C}$ for $20 \mathrm{~min}$, and then the optical density at $680 \mathrm{~nm}$ was recorded. Meantime, in the control group, casein solution and trichloroacetic acid were added in reverse order. The protein concentration in the fermentation broth was determined using a BCA proteins assay kit from Thermo Fisher Scientific (Waltham, MA, USA). The previous method was conducted to explore the buffering capacity of water extractives (Linde et al. 2006). The $\mathrm{pH}$ was measured by a pH meter PB-10 (Sartorius, Göttingen, Germany).

Statistical Package for the Social Sciences for Windows (SPSS Inc., Chicago, IL, USA, version 17.0) was used for orthogonal design and all statistical analyses, and a value of $\mathrm{p}<0.05$ was considered statistically significant. Values shown are means of triplicate measurements \pm standard deviation. The range method was introduced to analyze the results of the orthogonal experiment (Zhong et al. 2018). The number of bacteria was estimated by counting colony-forming units on LB agar plates in SHF and $\mathrm{SScF}$. Filter paper activity was measured for the cellulase activity of CTec 2 according to a previous study (Chan et al. 1989). 


\section{RESULTS AND DISCUSSION}

\section{Chemical Composition Analysis and Water Extraction}

To evaluate the potential of SMC as a feedstock for protease production, a composition analysis was performed. The SMC was composed of $24.8 \%$ cellulose, $17.6 \%$ hemicellulose, and 26.6\% lignin (Table 2). Although the holocellulose content (42.4\%) of SMC was lower than commonly used feedstocks, such as corn stover $(37.8 \%$ cellulose and $28.1 \%$ hemicellulose) (Yang and Wyman 2004), the holocellulose of SMC could be used for protease production. Compared to other biomass, a higher lignin content $(26.6 \%)$ of SMC results in a more recalcitrant structure of SMC. Therefore, it is necessary to adopt an efficient pretreatment method. The previously studied sodium chlorite pretreatment ( $\left.6 \% \mathrm{w} / \mathrm{v}, 2 \mathrm{~h}, 80{ }^{\circ} \mathrm{C}, 1: 10\right)$ was conducted on silvergrass (Nan et al. 2018). However, the enzymatic hydrolysis efficiency of pretreated SMC was $75.9 \%$ when the same pretreatment was performed on SMC. The higher enzymatic hydrolysis efficiency is supposed to be achieved under more severe conditions. Meanwhile, the water extract was reported to have significant impact on the pretreatment. Therefore, the water extraction of SMC was performed before pretreatment.

Previous studies have shown that the presence of water extract would affect the composition analysis of the material (Tamaki and Mazza 2010). Table 2 shows the composition of the water extractive-free SMC and raw SMC. The water-soluble extractive of SMC was $20.7 \%$. There was $1.38 \mathrm{~g} / \mathrm{L}$ protein in the water extract. The protein might be fungal extracellular secretion during the cultivation of mushrooms. 0.31 $\mathrm{g} / \mathrm{L}$ xylose and $0.25 \mathrm{~g} / \mathrm{L}$ arabinose were also detected in the water extract. In addition, $0.66 \mathrm{mg} / \mathrm{mL}$ of lactic acid was also detected in the water extract. The sugar and organic acid in water extract were also reported in a previous study (Asada et al. 2011). The content of cellulose, hemicellulose, and acid-insoluble lignin in the water extractive-free SMC significantly increased compared with that of the raw SMC, which was mainly attributed to weight loss during the water extraction process. In contrast, the content of acid-soluble lignin decreased, which might have been caused by the dissolution of watersoluble lignin and some chemicals with maximum absorption at around $240 \mathrm{~nm}$. The total content of acid soluble and insoluble lignin (30.0\%) in water extractive-free SMC was higher than that in raw SMC (26.6\%), which was consistent with the previous report (Martín et al. 2015).

\section{Sodium Chlorite Pretreatment}

The extractive-free solid was pretreated by sodium chlorite. Orthogonal design was applied to optimize sodium chlorite pretreatment conditions. The four key factors of pretreatment were studied. Each level of the four factors in the investigation was independent: A (ratio of solid to liquid: 2:15, 2:20, 2:25, and 2:30), B (time: $1 \mathrm{~h}, 2 \mathrm{~h}, 3 \mathrm{~h}$, and $4 \mathrm{~h}$ ), $\mathrm{C}$ (temperature: $65{ }^{\circ} \mathrm{C}, 70{ }^{\circ} \mathrm{C}, 75{ }^{\circ} \mathrm{C}$, and $80{ }^{\circ} \mathrm{C}$ ), and $\mathrm{D}$ (the concentration of sodium chlorite: $7 \% \mathrm{w} / \mathrm{v}, 8 \% \mathrm{w} / \mathrm{v}, 9 \% \mathrm{w} / \mathrm{v}$, and $10 \% \mathrm{w} / \mathrm{v})$. All factors were evaluated by an orthogonal $\mathrm{L}_{16}\left(4^{4}\right)$ design. The enzymatic efficiency was analyzed according to the statistical method.

The average values of $K$ for each factor at each level in the range analysis were named $K_{\mathrm{i}}$ (Table 3). According to the value of $K_{\mathrm{i}}$, the optimal pretreatment condition was $2: 25,4 \mathrm{~h}, 80{ }^{\circ} \mathrm{C}$, and $8 \%(\mathrm{w} / \mathrm{v})$. Based on the $\mathrm{R}$ value, the four factors influencing pretreatment were concluded to increase in this order: D $<$ A $<$ B $<$ C. The increase of cellulose content might have been attributed to the lignin removal. The enzymolysis 
efficiency of the pretreated SMC was $98.7 \%$ under the optimal condition, which was 3.5 and 6.9 times higher than that of extractive-free SMC and raw SMC, respectively. The lignin removal $(81.6 \%)$ was higher than that $(69.5 \%)$ reported in previous research (Zhu et al. 2013a). The reducing sugar yield reached $759 \mathrm{mg} / \mathrm{g}$, which was much higher than that $(323 \mathrm{mg} / \mathrm{g})$ of dilute-acid pretreated SMC (Kapu et al. 2012).

Table 2. Composition of Raw and Extracted SMC

\begin{tabular}{|c|c|c|}
\hline Composition (\% Dry Weight) & Raw SMC & Water Extracted SMC \\
\hline Cellulose (\%) & $24.78 \pm 0.62$ & $30.29 \pm 0.07$ \\
\hline Hemicellulose (\%) & $17.59 \pm 0.52$ & $21.59 \pm 0.11$ \\
\hline Acid Insoluble Lignin (\%) & $17.65 \pm 0.11$ & $24.25 \pm 0.05$ \\
\hline Acid Soluble Lignin (\%) & $8.98 \pm 0.11$ & $5.70 \pm 0.35$ \\
\hline Ash (\%) & $9.23 \pm 0.21$ & $8.62 \pm 0.16$ \\
\hline Petroleum Ether Extractives (\%) & $4.41 \pm 0.75$ & $/$ \\
\hline Water Soluble Extractives (\%) & $20.74 \pm 0.76$ & $/$ \\
\hline Enzymolysis Efficiency (\%) & $12.56 \pm 0.21$ & $21.84 \pm 1.15$ \\
\hline
\end{tabular}

Table 3. Results of Orthogonal Design

\begin{tabular}{|c|c|c|c|c|c|}
\hline Entry & Cellulose (\%) & $\begin{array}{c}\text { Hemicellulose } \\
(\%)\end{array}$ & Lignin (\%) & $\begin{array}{c}\text { Lignin } \\
\text { Removal }(\%)\end{array}$ & $\begin{array}{c}\text { Enzymolysis } \\
\text { Efficiency (\%) }\end{array}$ \\
\hline 1 & $45.94 \pm 0.61$ & $19.17 \pm 0.34$ & $12.57 \pm 0.16$ & 57.95 & $56.58 \pm 10.59$ \\
\hline 2 & $44.02 \pm 8.64$ & $18.82 \pm 3.97$ & $12.85 \pm 0.33$ & 57.02 & $55.25 \pm 5.56$ \\
\hline 3 & $39.27 \pm 4.18$ & $18.56 \pm 1.94$ & $17.93 \pm 0.63$ & 40.03 & $36.42 \pm 0.53$ \\
\hline 4 & $45.66 \pm 0.91$ & $19.46 \pm 0.18$ & $12.89 \pm 0.54$ & 56.89 & $53.00 \pm 7.87$ \\
\hline 5 & $51.01 \pm 4.87$ & $21.01 \pm 1.98$ & $11.34 \pm 0.64$ & 62.07 & $63.18 \pm 5.69$ \\
\hline 6 & $45.44 \pm 0.15$ & $19.04 \pm 0.18$ & $8.57 \pm 0.10$ & 71.34 & $64.96 \pm 2.01$ \\
\hline 7 & $42.14 \pm 5.19$ & $18.64 \pm 2.14$ & $12.10 \pm 0.74$ & 59.53 & $51.50 \pm 0.40$ \\
\hline 8 & $48.17 \pm 9.34$ & $19.76 \pm 4.05$ & $10.39 \pm 5.89$ & 65.25 & $72.21 \pm 1.60$ \\
\hline 9 & $44.75 \pm 1.36$ & $20.27 \pm 0.68$ & $12.59 \pm 0.98$ & 57.89 & $52.58 \pm 7.99$ \\
\hline 10 & $45.30 \pm 1.42$ & $18.88 \pm 0.45$ & $5.87 \pm 0.20$ & 80.37 & $80.37 \pm 3.93$ \\
\hline 11 & $46.88 \pm 1.46$ & $17.98 \pm 0.57$ & $9.42 \pm 0.42$ & 68.49 & $76.24 \pm 1.68$ \\
\hline 12 & $58.39 \pm 0.07$ & $24.41 \pm 0.26$ & $17.27 \pm 1.09$ & 42.24 & $37.42 \pm 2.45$ \\
\hline 13 & $44.96 \pm 1.38$ & $19.52 \pm 0.61$ & $11.52 \pm 0.15$ & 61.47 & $65.82 \pm 0.32$ \\
\hline 14 & $49.56 \pm 0.93$ & $22.92 \pm 4.40$ & $5.50 \pm 0.10$ & 81.61 & $98.71 \pm 6.54$ \\
\hline 15 & $48.20 \pm 0.93$ & $20.57 \pm 0.27$ & $11.41 \pm 1.27$ & 61.84 & $58.73 \pm 5.85$ \\
\hline 16 & $50.11 \pm 0.47$ & $20.38 \pm 0.78$ & $10.66 \pm 0.34$ & 64.34 & $59.08 \pm 8.96$ \\
\hline $\mathrm{K}_{1}$ & 47.85 & 60.76 & 65.9 & 63.91 & $/$ \\
\hline $\mathrm{K}_{2}$ & 50.31 & 62.96 & 61.65 & 70.59 & $/$ \\
\hline $\mathrm{K}_{3}$ & 46.11 & 57.44 & 66.82 & 75.16 & $/$ \\
\hline $\mathrm{K}_{4}$ & 61.93 & 63.95 & 55.75 & 63.88 & $/$ \\
\hline $\mathrm{R}$ & 18.05 & 20.27 & 29.05 & 8.2 & $/$ \\
\hline
\end{tabular}

Pretreatment was also conducted on raw SMC under the above optimal conditions. An enzymolysis efficiency of $89.5 \%$ was achieved, while the recovery of cellulose $(80.7 \%)$ and hemicellulose $(48.4 \%)$ decreased (Table 4$)$. The content of cellulose and hemicellulose after pretreatment on extractive-free SMC was higher. Moreover, cellulose and hemicellulose recovery for pretreatment on extractive-free SMC was also slightly enhanced, which was consistent with the previous report (Ballesteros et al. 2011). The reducing sugar yield of pretreated extractive-free SMC increased 19.3\% compared to pretreated SMC without water extraction. The enzymatic hydrolysis 
efficiency was also improved from $89.5 \%$ to $98.7 \%$. The water extract was found to be able to buffer $\mathrm{H}^{+}$(Fig. S1), and the ash had the same function as well (Vera et al. 2015; Li et al. 2016), both of which might reduce the pretreatment intensity. Additionally, the removal of xylose and arabinose by water extraction could reduce the formation of furfural, which was related to the decrease of enzyme activity (Chen et al. 2007). Therefore, the combination of water extraction and sodium chlorite pretreatment was an effective pretreatment process to produce a highly digestible SMC solid.

Table 4. Comparison of Pretreated SMCs

\begin{tabular}{|c|c|c|c|}
\hline Samples & $\begin{array}{c}\text { Pretreated } \\
\text { SMC }^{\mathrm{a}}\end{array}$ & $\begin{array}{c}\text { Pretreated SMC } \\
\text { Without Extraction } \\
\mathrm{b}\end{array}$ & $\begin{array}{c}\text { Pretreated SMC with } \\
\text { Extraction }^{\mathrm{c}}\end{array}$ \\
\hline Solid Recovery (\%) & $45.86 \pm 0.74$ & $45.00 \pm 0.45$ & $54.34 \pm 0.46$ \\
\hline Cellulose Recovery (\%) & $95.75 \pm 0.21$ & $80.74 \pm 0.17$ & $88.92 \pm 1.09$ \\
\hline Hemicellulose Recovery (\%) & $61.42 \pm 0.59$ & $48.40 \pm 0.10$ & $57.98 \pm 0.28$ \\
\hline Cellulose (\%) & $50.92 \pm 1.44$ & $44.46 \pm 0.9$ & $49.56 \pm 0.93$ \\
\hline Hemicellulose (\%) & $23.19 \pm 0.75$ & $18.92 \pm 4.40$ & $22.92 \pm 4.40$ \\
\hline Lignin (\%) & $10.57 \pm 1.70$ & $6.8 \pm 1.2$ & $5.50 \pm 0.10$ \\
\hline Enzymolysis Efficiency (\%) & $75.94 \pm 1.64$ & $89.54 \pm 1.79$ & $98.71 \pm 2.10$ \\
\hline
\end{tabular}

${ }^{a}$ The pretreatment conditions were: sodium chlorite concentration $6 \%(\mathrm{w} / \mathrm{v})$, ratio of solid to liquid $1: 10$, temperature $80^{\circ} \mathrm{C}$, time $2 \mathrm{~h}$ (Nan et al. 2018).

${ }^{b}$ The pretreatment condition was consistent with this study.

${ }^{c}$ Combined water extraction and sodium chlorite pretreatment were conducted on SMC under the condition optimized in this study.

\section{Structure of the Pretreated SMC}

The microstructures and crystallinity of the materials were characterized by SEM and XRD. The SEM images (Fig. S2) showed the difference between raw SMC and pretreated SMC. The surface of raw SMC was intact, flat, and compact, and the appearance of pretreated SMC was porous. According to microstructures of pretreated samples, it could be deduced that the lignin was partly removed and some of the cellulose was exposed, which improved the accessibility of enzyme. Thus, the enzymatic hydrolysis efficiency was improved. The crystallinity index $(\mathrm{CrI})$ of the lignocellulose is a primary obstacle against its accessibility to cellulase. To further investigate the recalcitrance of cellulose against the enzyme, X-ray diffraction was performed to determine the CrI of the materials (Fig. S3). The CrI of pretreated SMC (54.01\%) increased compared to raw SMC (39.8\%). This was attributed to the reduction of lignin content (Table 3). Additionally, the increased CrI might also be attributed to the extractive removal, as well as the removal of amorphous substances (Nan et al. 2018).

The changes of functional groups in raw and pretreated SMC were probed through FTIR (Fig. S4). The FTIR analysis showed that the carbonyl vibration peak $\left(1712 \mathrm{~cm}^{-1}\right)$ of pretreated SMC was enhanced, indicating that hemicellulose content increased after pretreatment (Diaz et al. 2015), which was consistent with the component analysis of pretreated samples. The signal peak $\left(1437 \mathrm{~cm}^{-1}\right)$ of the $\mathrm{CH}_{3}$ asymmetric groups in lignin decreased, which indicated the removal of lignin. Meanwhile, the absorption peak of $\mathrm{C}-\mathrm{O}$ stretching $\left(1305 \mathrm{~cm}^{-1}\right)$ in syringyls and $\mathrm{C}-\mathrm{C}$ bending $\left(1506 \mathrm{~cm}^{-1}\right)$ in aromatic groups were also significantly reduced (Diaz et al. 2015). These results suggested that sodium chlorite could remove lignin efficiently to facilitate enzymolysis of pretreated SMC. 


\section{SHF of Protease Production}

To optimize reducing sugar concentration, high sugar concentration hydrolysates were obtained at high-solid substrate loading. The eventual reducing sugar concentration reached $63.8 \mathrm{mg} / \mathrm{mL}, 126.5 \mathrm{mg} / \mathrm{mL}$, and $169.0 \mathrm{mg} / \mathrm{mL}$ at substrate loadings of $10 \%$, $20 \%$, and $30 \%$, respectively; the glucose concentration $(46.19 \mathrm{mg} / \mathrm{mL}, 92.76 \mathrm{mg} / \mathrm{mL}$, $122.79 \mathrm{mg} / \mathrm{mL}$, respectively) was superior to other pretreatment methods (Lu et al. 2010). The sugar concentration increased with increasing solid loading. The obtained hydrolysate at $30 \%$ solid loading was diluted to the desired concentration for protease production. As shown in Fig. 1b, the enzyme activity increased significantly $(\mathrm{p}<0.05)$ with the increase of sugar concentration. In contrast, the obtained protease yield (U protease/mg reducing sugar) decreased with increasing sugar concentration (Table 5), which was consistent with previous studies (Singh et al. 2004).

(a)
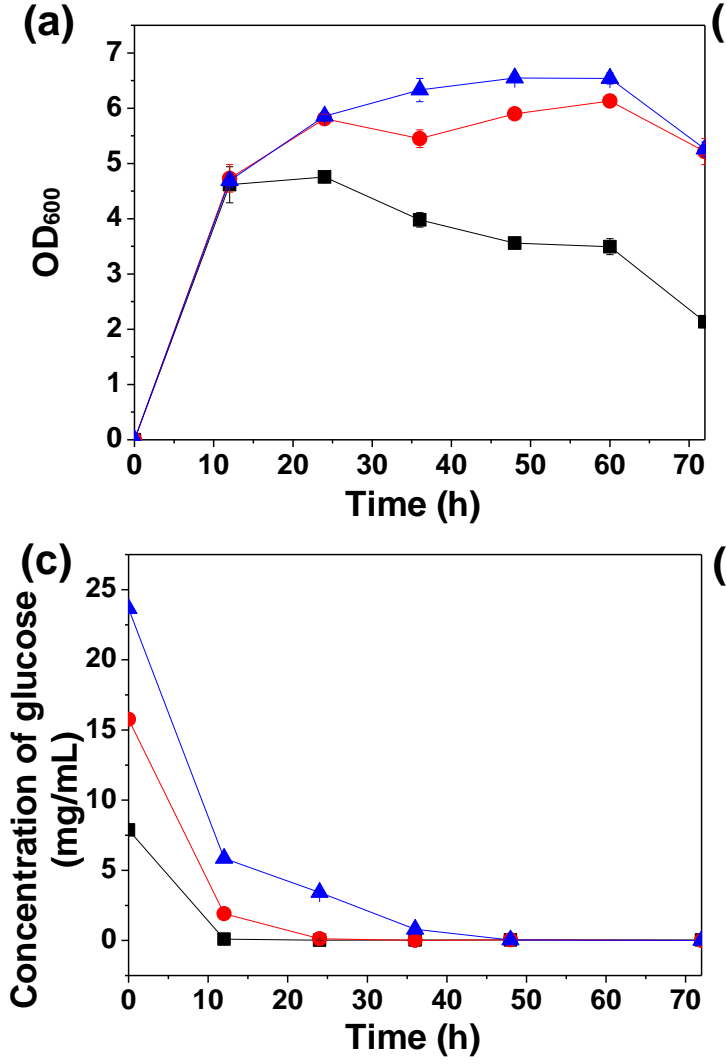

(b)

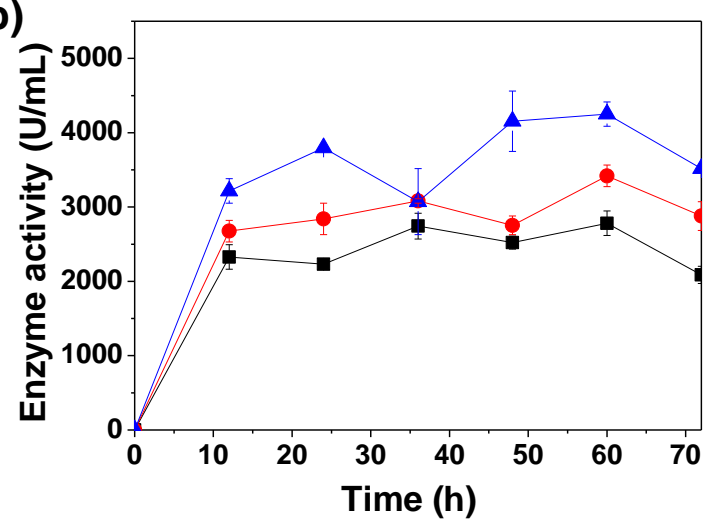

(d)

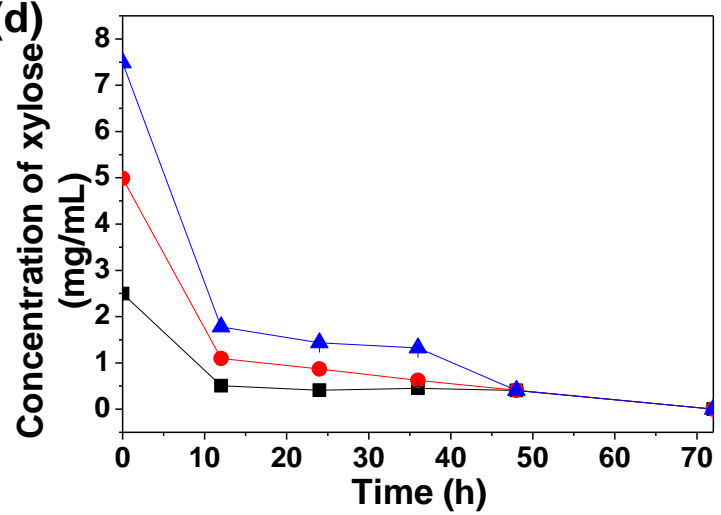

Fig. 1. Fermentation parameters at different initial total reducing sugar concentrations: $\mathrm{OD}_{600}(\mathrm{a})$; enzyme activity (b); concentration of glucose (c); and concentration of xylose (d) Legend: $-10 \mathrm{mg} / \mathrm{mL} ; \bullet 20 \mathrm{mg} / \mathrm{mL} ; \Delta 30 \mathrm{mg} / \mathrm{mL}$

Table 5. SHF Process for Protease Production

\begin{tabular}{|c|c|c|c|c|c|}
\hline $\begin{array}{c}\text { Sugar } \\
\text { Concentration } \\
(\mathrm{mg} / \mathrm{mL})\end{array}$ & $\begin{array}{c}\text { Protease } \\
\text { Activity } \\
(\mathrm{U} / \mathrm{mL})\end{array}$ & $\begin{array}{c}\text { Time } \\
(\mathrm{h})\end{array}$ & $\begin{array}{c}\text { Protease } \\
\text { Productivity } \\
(\mathrm{U} / \mathrm{mL} / \mathrm{h})\end{array}$ & Yp/s $(\mathrm{U} / \mathrm{mg})$ & $\begin{array}{c}\text { Cell Density } \\
(\mathrm{CFU} / \mathrm{mL})\end{array}$ \\
\hline 10 & $2782 \pm 164$ & 60 & 46.36 & 278.2 & $1.8 \times 10^{10}$ \\
\hline 20 & $3419 \pm 144$ & 60 & 56.98 & 170.95 & $3.1 \times 10^{10}$ \\
\hline 30 & $4250 \pm 164$ & 60 & 70.83 & 141.67 & $3.3 \times 10^{10}$ \\
\hline
\end{tabular}


It was reported that under high initial glucose concentration, some glucose would be converted into viscous material in the cultures, which led to the fermentation becoming unusable. Furthermore, the metabolites would affect the formation of protease. During the fermentation, glucose, as a preferred carbon, did not repress the utilization of xylose, but its consumption rate was much higher than xylose (Fig. 1c and 1d), which was consistent with a previous study (Zhang et al. 2016). There was no significant difference $(\mathrm{p}>0.05)$ in the maximal $\mathrm{OD}_{600}(60 \mathrm{~h})$ between $20 \mathrm{mg} / \mathrm{mL}$ and $30 \mathrm{mg} / \mathrm{mL}$. It was speculated that higher glucose concentration would impact the growth of Bacillus subtilis DES-59 (Mehta et al. 2006). However, protease productivity of SHF was low due to the 96-h enzymatic hydrolysis. Furthermore, the initial high sugar concentration affected protease production. Hence, the $\mathrm{SScF}$ process was introduced for protease production, during which the sugar was slowly released.

\section{Effect of Water Extract of SMC on the Enzymatic Hydrolysis and the Growth of Bacillus subtilis DES-59}

The $30 \%, 60 \%$, and $90 \%$ (V/V) water extract was added to investigate the effect of water extract on enzymatic hydrolysis of pretreated SMC. There was no significant difference $(\mathrm{p}>0.05)$ in reducing sugar yield (Fig. 2a). Phenols in water extractive were reported to hinder degradation of the substrate. In this study, the water extract showed no influence on digestion of pretreated SMC according to the reducing sugar yield. This could be due to the presence of proteins in the water extract, which could promote the digestion of cellulose (Smit and Huijgen 2017). In addition, the water extract showed buffering capability. Hence, water extract was recycled as an alternative to sodium citrate buffer.
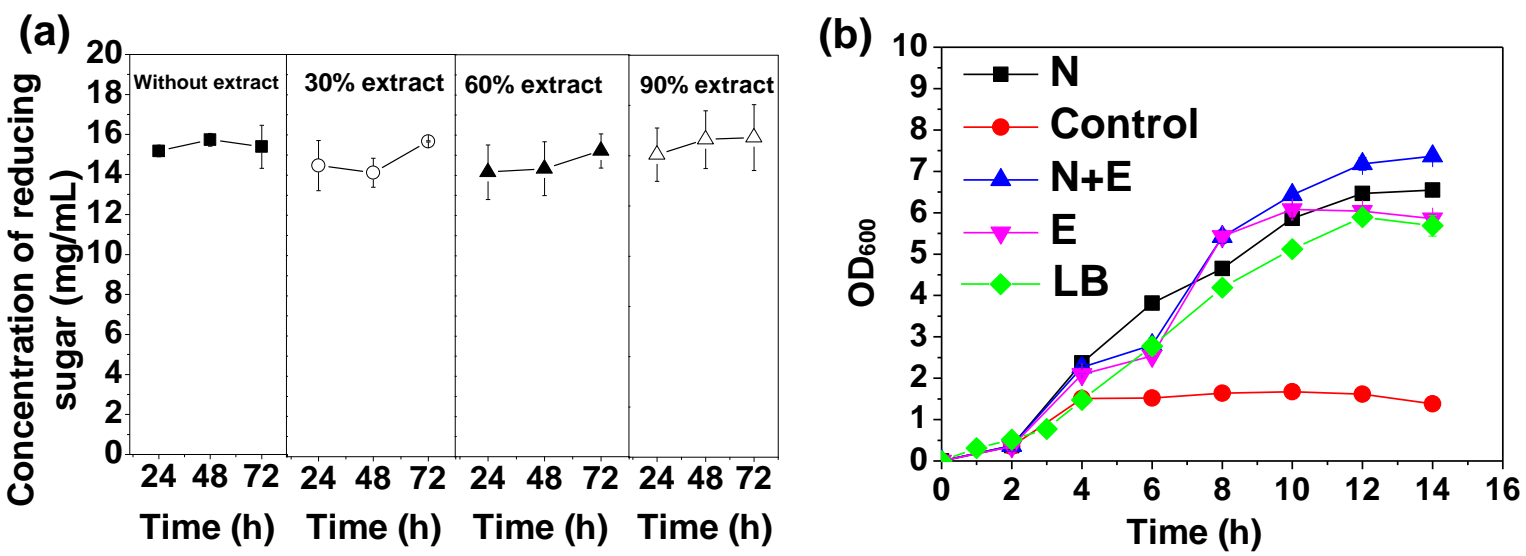

Fig. 2. Effect of water extractives on enzymatic hydrolysis of pretreated SMC and growth of Bacillus subtilis DES-59: (a) Concentration of reducing sugar during the enzymatic hydrolysis, (b) $\mathrm{OD}_{600}$ of Bacillus subtilis DES-59 during the fermentation. Control represents the medium without $\left(\mathrm{NH}_{4}\right)_{2} \mathrm{SO}_{4}$ and water-extract liquid; $\mathrm{N}$ represents the medium with $\left(\mathrm{NH}_{4}\right)_{2} \mathrm{SO}_{4}$ addition; $\mathrm{N}+\mathrm{E}$ represents the medium with $\left(\mathrm{NH}_{4}\right)_{2} \mathrm{SO}_{4}$ and water-extract liquid addition; and $\mathrm{E}$ represents the medium with water-extract liquid addition; LB represents the LB medium.

Bacillus subtilis DES-59 was cultured in hydrolysates with and without water extract. The $\mathrm{OD}_{600}$ of the control, N, E, and N+E were 1.62, 6.47, 6.04, and 7.18 at $12 \mathrm{~h}$, respectively. $\mathrm{OD}_{600}$ in $\mathrm{LB}$ medium (5.895) was lower than that in $\mathrm{N}+\mathrm{E}$ medium (7.18) at $12 \mathrm{~h}$. This may due to the different carbon sources. Reducing sugar was more conducive to the growth of Bacillus subtilis. In Fig. 2b, cell density in the $\mathrm{E}$ and $\mathrm{N}+\mathrm{E}$ media was 
higher than the control and $\mathrm{N}$ mediums, respectively, which might be attributed to the proteins, inorganic salt, organic acid and sugars in the water extract. From $2 \mathrm{~h}$ to $12 \mathrm{~h}$, the average specific growth rates of $0.297 \mathrm{~h}^{-1}$ and $0.285 \mathrm{~h}^{-1}$ were achieved in $\mathrm{N}+\mathrm{E}$ and $\mathrm{E}$ media, respectively, indicating that water extract of SMC is beneficial to the growth of Bacillus subtilis. Previous research mainly focused on the antibacterial effect of water extract (Ahn et al. 2007). In this study, the water extract of SMC was demonstrated to increase the growth of Bacillus subtilis.

\section{SScF of Pretreated SMC}

For $\mathrm{SScF}, 2773 \mathrm{U} / \mathrm{mL}$ protease was obtained with a specific activity of $561 \mathrm{U} / \mathrm{mg}$ under $20 \mathrm{mg} / \mathrm{mL}$ solid loading (Table 6). $2675 \mathrm{U} / \mathrm{mg}$ protease was produced at $12 \mathrm{~h}$ with $20 \mathrm{mg} / \mathrm{mL}$ substrate in SHF. Considering the 72-h enzymatic hydrolysis, the productivity of SHF was $32 \mathrm{U} / \mathrm{mL} / \mathrm{h}$, which was significantly lower to $231 \mathrm{U} / \mathrm{mL} / \mathrm{h}$ of $\mathrm{SScF}$. In addition, with the addition of water extract, enzyme activity $(3096 \mathrm{U} / \mathrm{mL}$ ) increased $11.64 \%$ at $20 \mathrm{mg} / \mathrm{mL}$ solid loading. Metal ions in the water extract might have had a positive influence on enzyme activity via improving stability of protease as co-factors (Hansen et al. 2015). Meanwhile, protein concentration $(6.02 \mathrm{mg} / \mathrm{mL})$ was also increased by $21.9 \%$, possibly due to increasing cell density $\left(2.16 \times 10^{10} \mathrm{CFU} / \mathrm{mL}\right)$ and then promotion of the secretion of proteins. Higher enzyme activity of the culture was achieved by increasing the solid loading of the medium. The $4692 \mathrm{U} / \mathrm{mL}$ and $5518 \mathrm{U} / \mathrm{mL}$ $(60 \mathrm{~h})$ proteases were obtained at $40 \mathrm{mg} / \mathrm{mL}$ and $60 \mathrm{mg} / \mathrm{mL}$ solid loadings, respectively. In contrast, enzyme productivity declined due to extended fermentation time. The absence of sugar during $\mathrm{SScF}$ fermentation indicated that sugar in the water extract was also consumed. Furthermore, the productivity was improved compared with SHF. Therefore, it is feasible to apply SScF for protease production. Considering the process cost, the lower enzyme loadings were investigated under $60 \mathrm{mg} / \mathrm{mL}$ solid loading. The $5227 \mathrm{U} / \mathrm{mL}, 5306 \mathrm{U} / \mathrm{mL}$, and $5331 \mathrm{U} / \mathrm{mL}(60 \mathrm{~h})$ proteases were obtained at $5 \mathrm{FPU} / \mathrm{g}, 10$ FPU/g, and 15 FPU/g enzyme loadings, respectively. The comparative enzyme activity was achieved with a lower enzyme loading of $5 \mathrm{FPU} / \mathrm{g}$. Compared with the addition of 8 FPU/g enzymes for lactic acid production, it was more economical (Zhang et al. 2016).

Table 6. SScF Process for Protease Production

\begin{tabular}{|c|c|c|c|c|}
\hline & $\begin{array}{c}\text { Without } \\
\text { Water } \\
\text { Extractives }\end{array}$ & \multicolumn{3}{|c|}{ With Water Extractives } \\
\hline Solid Loading $(\mathrm{mg} / \mathrm{mL})$ & 20 & 20 & 40 & 60 \\
\hline Protein Concentration $(\mathrm{mg} / \mathrm{mL})$ & $4.94 \pm 0.33$ & $6.02 \pm 1.22$ & $12.92 \pm 1.83$ & $13.70 \pm 0.99$ \\
\hline Protease Activity $(\mathrm{U} / \mathrm{mL})$ & $2773 \pm 136$ & $3096 \pm 219$ & $4692 \pm 64$ & $5518 \pm 103$ \\
\hline Specific Activity $(\mathrm{U} / \mathrm{mg} \mathrm{protein})$ & 561 & 514 & 363 & 403 \\
\hline Time $(\mathrm{h})$ & 12 & 12 & 60 & 60 \\
\hline Protease Productivity $(\mathrm{U} / \mathrm{mL} / \mathrm{h})$ & 231.08 & 258.92 & 78.2 & 91.96 \\
\hline Cell Density $(\mathrm{CFU} / \mathrm{mL})$ & $1.79 \times 10^{10}$ & $2.16 \times 10^{10}$ & $1.70 \times 10^{11}$ & $2.01 \times 10^{11}$ \\
\hline
\end{tabular}

At the end of fermentation, the obtained residues were mainly composed of ash, lignin, and Bacillus subtilis. Previous study showed that Bacillus subtilis was beneficial to plant growth (López-Valdez et al. 2011). Lignin exhibited excellent adsorption capacity for heavy metals, and could be used as a natural urease inhibitor to promote the retention of urea in soil. In addition, as a humic acid precursor, lignin could be degraded 
into humus to improve soil fertility (Legras-Lecarpentier et al. 2019). Considering the above advantages, it is feasible to convert fermentation residue into fertilizer that provides nutrients and essential elements for plant growth.

In this study, the $\mathrm{SScF}$ was conducted to produce protease more efficiently than previous studies (Kshetri et al. 2016; Mishra 2016; Singh and Bajaj 2016). Furthermore, the water extract of SMC was recycled for protease production in SScF. The pretreated SMC was the only carbon source in present research, while previous studies required additional carbon sources (Singh and Bajaj 2016; Hussain et al. 2017). The established process provided an alternative method for closed-loop utilization of an inexpensive and not easily degradable substrate.

\section{Mass Balance}

It was determined that $0.79 \mathrm{~kg}$ extractive-free $\mathrm{SMC}$ was obtained from $1 \mathrm{~kg}$ raw SMC. After the pretreatment, $0.45 \mathrm{~kg}$ substrate was recovered, which could be used for protease production by SScF with Bacillus subtilis DES-59. Meanwhile, $0.11 \mathrm{~kg}$ fertilizer was obtained. The co-production of protease and fertilizer was achieved by SScF. Traditionally, the residues of enzymatic hydrolysis should be blended with bacteria for fertilizer production. Here, residue of $\mathrm{SScF}$ might be directly used for fertilizer. Therefore, the developed $\mathrm{SScF}$ process exhibited potential application in future biorefinery.

\section{CONCLUSIONS}

1. The enzymatic hydrolysis efficiency of SMC was improved significantly with the established pretreatment.

2. The water extract of SMC was recycled to promote protease production by Bacillus subtilis DES-59.

3. The residues after $\mathrm{SScF}$ were recovered as fertilizer.

4. A closed-loop process of simultaneous saccharification and protease production from SMC by Bacillus subtilis DES-59 was successfully established.

\section{ACKNOWLEDGMENTS}

This study was financially supported by the National Natural Science Foundation of China (Grant No. 51878291).

\section{REFERENCES CITED}

Abdel-Fattah, A. F., and Abdel-Naby, M. A. (2012). "Pretreatment and enzymic saccharification of water hyacinth cellulose," Carbohyd. Polym. 87(3), 2109-2113. DOI: $10.1016 /$ j.carbpol.2011.10.033

Ahn, J., Grün, I. U., and Mustapha, A. (2007). "Effects of plant extracts on microbial growth, color change, and lipid oxidation in cooked beef," Food Microbiol. 24(1), 7- 
14. DOI: $10.1016 /$ j.fm.2006.04.006

An, Q., Wang, J.-L., Wang, Y.-T., Lin, Z.-L., and Zhu, M.-J. (2018). "Investigation on hydrogen production from paper sludge without inoculation and its enhancement by Clostridium thermocellum," Bioresource Technol. 263, 120-127. DOI: 10.1016/j.biortech.2018.04.105

Asada, C., Asakawa, A., Sasaki, C., and Nakamura, Y. (2011). "Characterization of the steam-exploded spent Shiitake mushroom medium and its efficient conversion to ethanol," Bioresource Technol. 102(21), 10052-10056. DOI:

10.1016/j.biortech.2011.08.020

Ballesteros, I., Ballesteros, M., Cara, C., Sáez, F., Castro, E., Manzanares, P., Negro, M. J., and Oliva, J. M. (2011). "Effect of water extraction on sugars recovery from steam exploded olive tree pruning," Bioresource Technol. 102(11), 6611-6616. DOI: 10.1016/j.biortech.2011.03.077

Borhani, M. S., Etemadifar, Z., Emtiazi, G., and Jorjani, E. (2018). "A statistical approach for production improvement of a neutral protease from a newly isolated strain of Aeromonas hydrophila," Iran. J. Sci. Technol. A. 42(4), 1771-1778. DOI: 10.1007/s40995-017-0444-1

Cannella, D., and Jørgensen, H. (2014). "Do new cellulolytic enzyme preparations affect the industrial strategies for high solids lignocellulosic ethanol production," Biotechnol. Bioeng. 111(1), 59-68. DOI: 10.1002/bit.25098

Carrasco, J., Zied, D. C., Pardo, J. E., Preston, G. M., and Pardo-Giménez, A. (2018). "Supplementation in mushroom crops and its impact on yield and quality," $A M B$ Express 8(1), 1-9. DOI:10.1186/s13568-018-0678-0

Cerda, A., Mejias, L., Rodríguez, P., Rodríguez, A., Artola, A., Font, X., Gea, T., and Sánchez, A. (2019). "Valorisation of digestate from biowaste through solid-state fermentation to obtain value added bioproducts: A first approach," Bioresource Technol. 271, 409-416. DOI: 10.1016/j.biortech.2018.09.131

Chan, M., Breuil, C., Schwald, W., and Saddler, J. N. (1989). "Comparison of methods for quantifying the hydrolytic potential of cellulase enzymes," Appl. Microbiol. Biot. 31(4), 413-418. DOI: 10.1007/BF00257614

Chen, S.-F., Mowery, R. A., Scarlata, C. J., and Chambliss, C. K. (2007). "Compositional analysis of water-soluble materials in corn stover," J. Agr. Food Chem. 55(15), 59125918. DOI: $10.1021 /$ jf0700327

Diaz, A. B., De Souza Moretti, M. M., Bezerra-Bussoli, C., Da Costa Carreira Nunes, C., Blandino, A., Da Silva, R., and Gomes, E. (2015). "Evaluation of microwave-assisted pretreatment of lignocellulosic biomass immersed in alkaline glycerol for fermentable sugars production," Bioresource Technol. 185, 316-323. DOI:

10.1016/j.biortech.2015.02.112

Elsamadony, M., and Tawfik, A. (2018). "Maximization of hydrogen fermentative process from delignified water hyacinth using sodium chlorite," Energ. Convers. Manage. 157, 257-265. DOI: 10.1016/j.enconman.2017.12.013

Gomes, D., Gomes, J., and Steiner, W. (1994). "Production of highly thermostable xylanase by a wild strain of thermophilic fungus Thermoascus aurantiacus and partial characterization of the enzyme," J. Biotechnol. 37(1), 11-22. DOI: 10.1016/01681656(94)90197-X

Hansen, G. H., Lübeck, M., Frisvad, J. C., Lübeck, P. S., and Andersen, B. (2015). "Production of cellulolytic enzymes from ascomycetes: Comparison of solid state and submerged fermentation," Process Biochem. 50(9), 1327-1341. DOI: 


\subsection{6/j.procbio.2015.05.017}

Hmidet, N., Ali, N. E.-H., Haddar, A., Kanoun, S., Alya, S.-K., and Nasri, M. (2009).

"Alkaline proteases and thermostable $\alpha$-amylase co-produced by Bacillus licheniformis NH1: Characterization and potential application as detergent additive," Biochem. Eng. J. 47(1-3), 71-79. DOI: 10.1016/j.bej.2009.07.005

Hong, Y.-Y., Wang, Y.-T., Zhu, S.-M., Luo, X.-C., Li, S., Zhuo, M., Zhou, T., and Zhu, M.-J. (2019). "Improved enzymatic hydrolysis and ethanol production by combined alkaline peroxide and ionic liquid-water mixtures pretreatment of rice straw," $J$. Chem. Technol. Biot. 94(5), 1451-1459. DOI: 10.1002/jctb.5895

Hubbell, C. A., and Ragauskas, A. J. (2010). "Effect of acid-chlorite delignification on cellulose degree of polymerization," Bioresource Technol. 101(19), 7410-7415. DOI: 10.1016/j.biortech.2010.04.029

Hussain, F., Kamal, S., Rehman, S., Azeem, M., Bibi, I., Ahmed, T., and Iqbal, H. M. N. (2017). "Alkaline protease production using response surface methodology, characterization and industrial exploitation of alkaline protease of Bacillus subtilis sp.," Catal. Lett. 147(5), 1204-1213. DOI: 10.1007/s10562-017-2017-5

Kapu, N. U. S., Manning, M., Hurley, T. B., Voigt, J., Cosgrove, D. J., and Romaine, C. P. (2012). "Surfactant-assisted pretreatment and enzymatic hydrolysis of spent mushroom compost for the production of sugars," Bioresource Technol. 114, 399-405. DOI: 10.1016/j.biortech.2012.02.139

Kshetri, P., Ningombam, O., and Ningthoujam, D. S. (2016). "Optimization of alkaline protease production by alkaliphilic Bacillus sp. KW2 in low cost medium using statistical approaches," Appl. Microbiol. 2(3), Article ID 1000117. DOI: 10.4172/2471-9315.1000117

Legras-Lecarpentier, D., Stadler, K., Weiss, R., Guebitz, G. M., and Nyanhongo, G. S. (2019). "Enzymatic synthesis of 100\% lignin biobased granules as fertilizer storage and controlled slow release systems," ACS Sustain. Chem. Eng. 7(14), 12621-12628. DOI: 10.1021/acssuschemeng.9b02689

Li, Z., Yu, Y., Sun, J., Li, D., Huang, Y., and Feng, Y. (2016). "Effect of extractives on digestibility of cellulose in corn stover with liquid hot water pretreatment," BioResources 11(1), 54-70. DOI: 10.15376/biores.11.1.54-70

Lin, H.-N., Wang, Y.-T., and Zhu, M.-J. (2017). "Evaluation of spent mushroom compost as a lignocellulosic substrate for hydrogen production by Clostridium thermocellum," Int. J. Hydrogen Energ. 42(43), 26687-26694. DOI: 10.1016/j.ijhydene.2017.09.040

Linde, M., Galb, M., and Zacchi, G. (2006). "Steam pretreatment of acid-sprayed and acid-soaked barley straw for production of ethanol," Appl. Biochem. Biotech. 130(13), 546-562. DOI: 10.1385/Abab:130:1:546

López-Valdez, F., Fernández-Luqueño, F., Ceballos-Ramírez, J. M., Marsch, R., OlaldePortugal, V., and Dendooven, L. (2011). "A strain of Bacillus subtilis stimulates sunflower growth (Helianthus annuus L.) temporarily," Sci. Hortic.-Amsterdam 128(4), 499-505. DOI: 10.1016/j.scienta.2011.02.006

Lu, Y., Wang, Y., Xu, G., Chu, J., Zhuang, Y., and Zhang, S. (2010). "Influence of high solid concentration on enzymatic hydrolysis and fermentation of steam-exploded corn stover biomass," Appl. Biochem. Biotech. 160(2), 360-369. DOI: 10.1007/s12010008-8306-0

Martín, C., García, A., Schreiber, A., Puls, J., and Saake, B. (2015). "Combination of water extraction with dilute-sulphuric acid pretreatment for enhancing the enzymatic hydrolysis of Jatropha curcas shells," Ind. Crop. Prod. 64, 233-241. DOI: 
10.1016/j.indcrop.2014.09.040

Mehta, V. J., Thumar, J. T., and Singh, S. P. (2006). "Production of alkaline protease from an alkaliphilic actinomycete," Bioresource Technol. 97(14), 1650-1654. DOI: 10.1016/j.biortech.2005.07.023

Mishra, V. K. (2016). "Optimization of thermotolerant alkaline protease production from Brevibacillus brevis strain BT2 using surface response methodology," Biocatalysis and Agricultural Biotechnology 7, 87-94. DOI: 10.1016/j.bcab.2016.05.008

Nan, Y., Jia, L., Yang, M., Xin, D., Qin, Y., and Zhang, J. (2018). "Simplified sodium chlorite pretreatment for carbohydrates retention and efficient enzymatic saccharification of silvergrass," Bioresource Technol. 261, 223-231. DOI: 10.1016/j.biortech.2018.03.106

Quintanar-Orozco, E. T., Vázquez-Rodriguez, G. A., Beltrán-Hernández, R. I., LuchoConstantino, C. A., Coronel-Olivares, C., Montiel, S. G., and Islas-Valdez, S. (2018). "Enhancement of the biogas and biofertilizer production from Opuntia heliabravoana Scheinvar," Environ. Sci. Pollut. Res. 25(28), 28403-28412. DOI: 10.1007/s11356018-2845-X

Singh, J., Vohra, R., and Sahoo, D. K. (2004). "Enhanced production of alkaline proteases by Bacillus sphaericus using fed-batch culture," Process Biochem. 39(9), 1093-1101. DOI: 10.1016/S0032-9592(03)00217-6

Singh, S., and Bajaj, B. K. (2016). "Bioprocess optimization for production of thermoalkali-stable protease from Bacillus subtilis K-1 under solid-state fermentation," Prep. Biochem. Biotech. 46(7), 717-724. DOI: 10.1080/10826068.2015.1135455

Sluiter, A., Hames, B., Ruiz, R., Scarlata, C., Sluiter, J., Templeton, D., and Crocker, D. (2012). Determination of Structural Carbohydrates and Lignin in Biomass (NREL/TP-510-42618), National Renewable Energy Laboratory, Golden, CO, USA.

Smit, A. T., and Huijgen, W. J. J. (2017). "The promotional effect of water-soluble extractives on the enzymatic cellulose hydrolysis of pretreated wheat straw," Bioresource Technol. 243, 994-999. DOI: 10.1016/j.biortech.2017.07.072

Smitha, G. R., Basak, B. B., Thondaiman, V., and Saha, A. (2019). "Nutrient management through organics, bio-fertilizers and crop residues improves growth, yield and quality of sacred basil (Ocimum sanctum Linn)," Ind. Crop. Prod. 128, 599-606. DOI: 10.1016/j.indcrop.2018.11.058

Tamaki, Y., and Mazza, G. (2010). "Measurement of structural carbohydrates, lignins, and micro-components of straw and shives: Effects of extractives, particle size and crop species," Ind. Crop. Prod. 31(3), 534-541. DOI: 10.1016/j.indcrop.2010.02.004

Vera, R. M., Bura, R., and Gustafson, R. (2015). "Synergistic effects of mixing hybrid poplar and wheat straw biomass for bioconversion processes," Biotechnol. Biofuels 8, Article Number 226. DOI: 10.1186/s13068-015-0414-9

Xu, Y., Li, J., Zhang, M., and Wang, D. (2018). "Modified simultaneous saccharification and fermentation to enhance bioethanol titers and yields," Fuel 215, 647-654. DOI: 10.1016/j.fuel.2017.11.072

Yang, B., and Wyman, C. E. (2004). "Effect of xylan and lignin removal by batch and flowthrough pretreatment on the enzymatic digestibility of corn stover cellulose," Biotechnol. Bioeng. 86(1), 88-98. DOI: 10.1002/bit.20043

Yu, Z., Jameel, H., Chang, H.-M., and Park, S. (2011). "The effect of delignification of forest biomass on enzymatic hydrolysis," Bioresource Technol. 102(19), 9083-9089. DOI: 10.1016/j.biortech.2011.07.001 
Zhang, T., and Zhu, M.-J. (2016). "Enhancing enzymolysis and fermentation efficiency of sugarcane bagasse by synergistic pretreatment of Fenton reaction and sodium hydroxide extraction," Bioresource Technol. 214, 769-777. DOI: 10.1016/j.biortech.2016.05.032

Zhang, Y., Kumar, A., Hardwidge, P. R., Tanaka, T., Kondo, A., and Vadlani, P. V. (2016). "d-lactic acid production from renewable lignocellulosic biomass via genetically modified Lactobacillus plantarum," Biotechnol. Progr. 32(2), 271-278. DOI: 10.1002/btpr.2212

Zhong, L.-X., Zhang, X., Tang, C.-L., Chen, Y.-J., Shen, T., Zhu, C.-J., and Ying, H. (2018). "Hydrazine hydrate and organosolv synergetic pretreatment of corn stover to enhance enzymatic saccharification and co-production of high-quality antioxidant lignin," Bioresource Technol. 268, 677-683. DOI: 10.1016/j.biortech.2018.08.063

Zhu, H.-J., Liu, J.-H., Sun, L.-F., Hu, Z.-F., and Qiao, J.-J. (2013a). "Combined alkali and acid pretreatment of spent mushroom substrate for reducing sugar and biofertilizer production," Bioresource Technol. 136, 257-266. DOI:

10.1016/j.biortech.2013.02.121

Zhu, M.-J., Cheng, J.-R., Chen, H.-T., Deng, M.-C., and Xie, W.-H. (2013b). "Optimization of neutral protease production from Bacillus subtilis: Using agroindustrial residues as substrates and response surface methodology," Biotechnol. Appl. Bioc. 60(3), 336-342. DOI: 10.1002/bab.1094

Zhu, Y., Chang, Y., Guan, J., Shanguan, G., and Xin, F. (2016). "Butanol production from organosolv treated spent mushroom substrate integrated with in situ biodiesel extraction," Renew. Energ. 96, 656-661. DOI: 10.1016/j.renene.2016.04.048

Article submitted: November 16, 2019; Peer review completed: February 29, 2020; Revised version received and accepted: March 15, 2020; Published: March 20, 2020. DOI: 10.15376/biores. 15.2.3201-3218 


\section{APPENDIX}

\section{Supplementary Information}

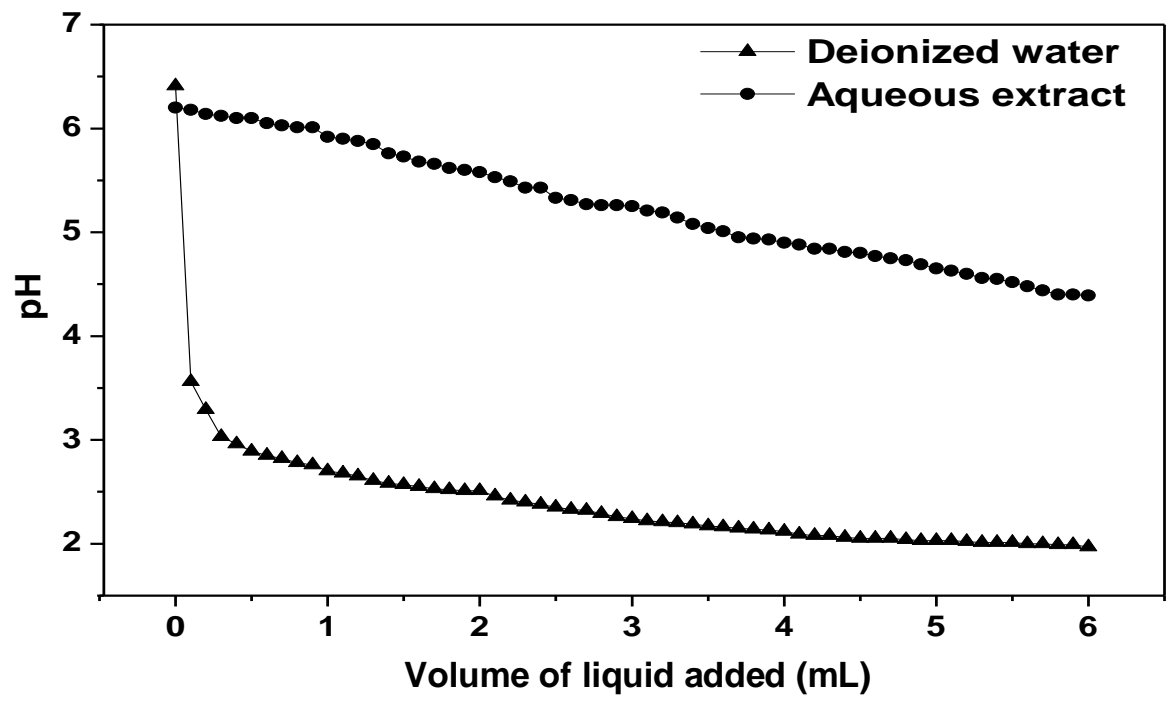

Fig. S1. Titration curve with $0.1 \mathrm{M} \mathrm{H}_{2} \mathrm{SO}_{4}$ for deionized water and aqueous extract


Fig. S2. SEM images of raw (a) and pretreated SMC (b). The images correspond to $2000 \times$ magnification 


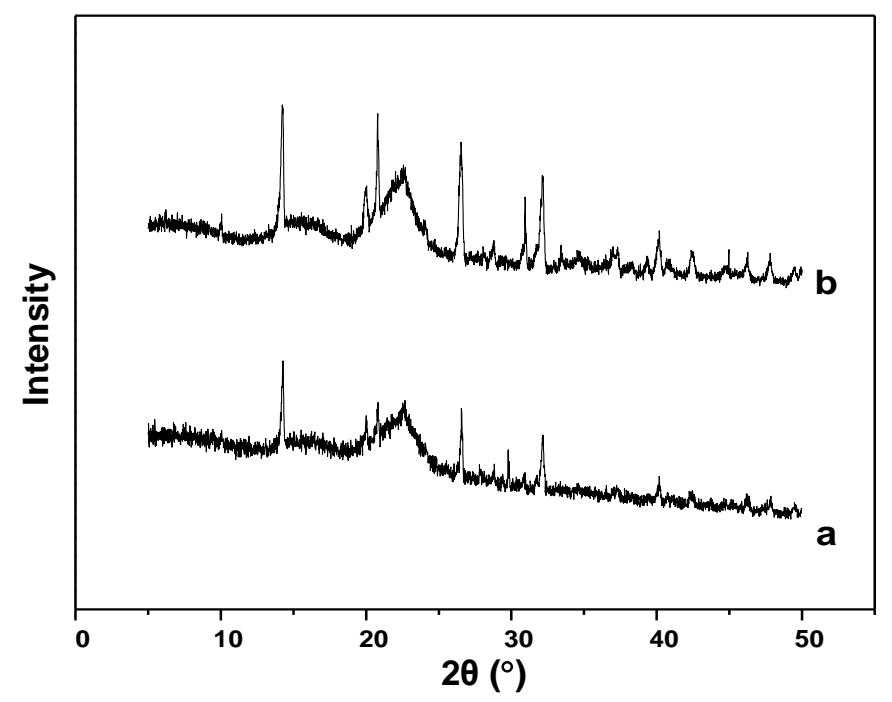

Fig. S3. X-ray diffraction pattern of raw SMC samples: (a) Raw SMC; (b) Pretreated SMC

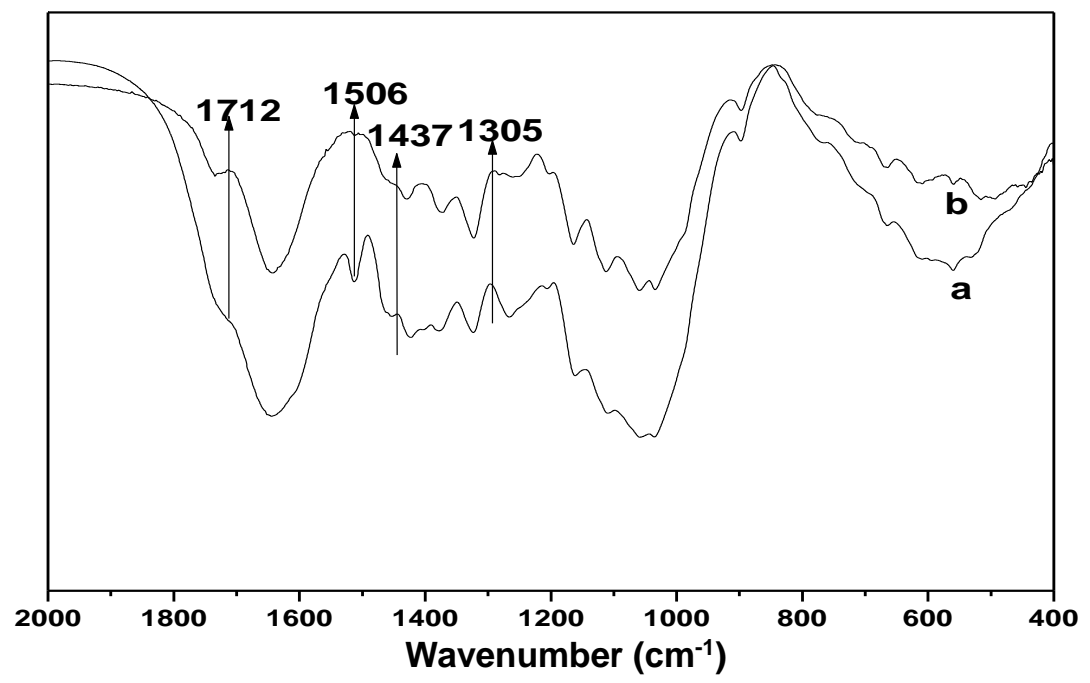

Fig. S4. The FITR spectra of SMC samples: (a) Raw SMC; (b) Pretreated SMC 